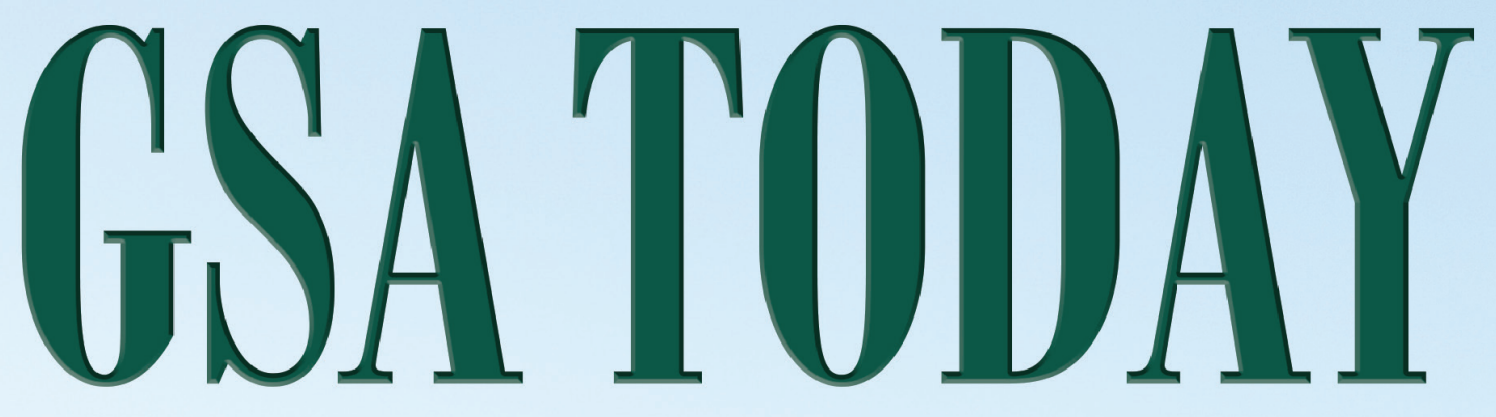

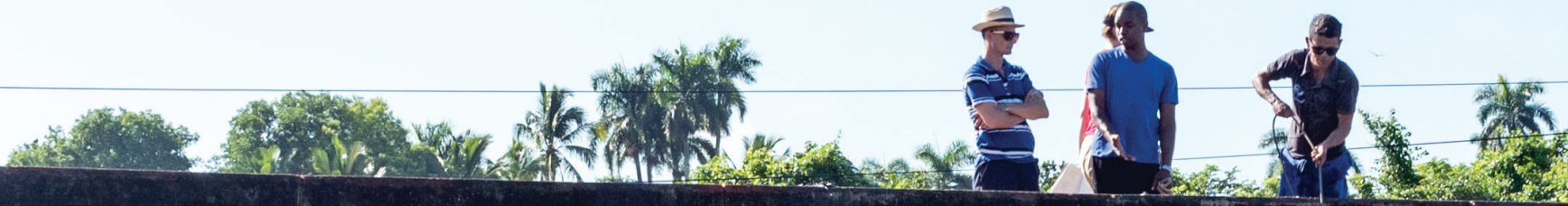

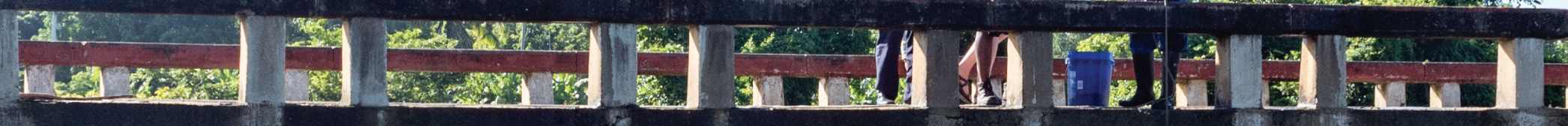

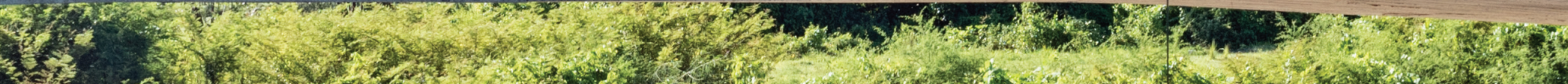
3.5.

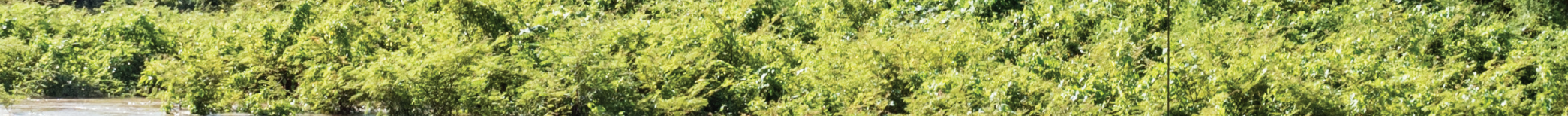

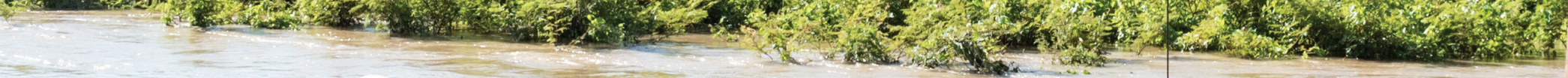

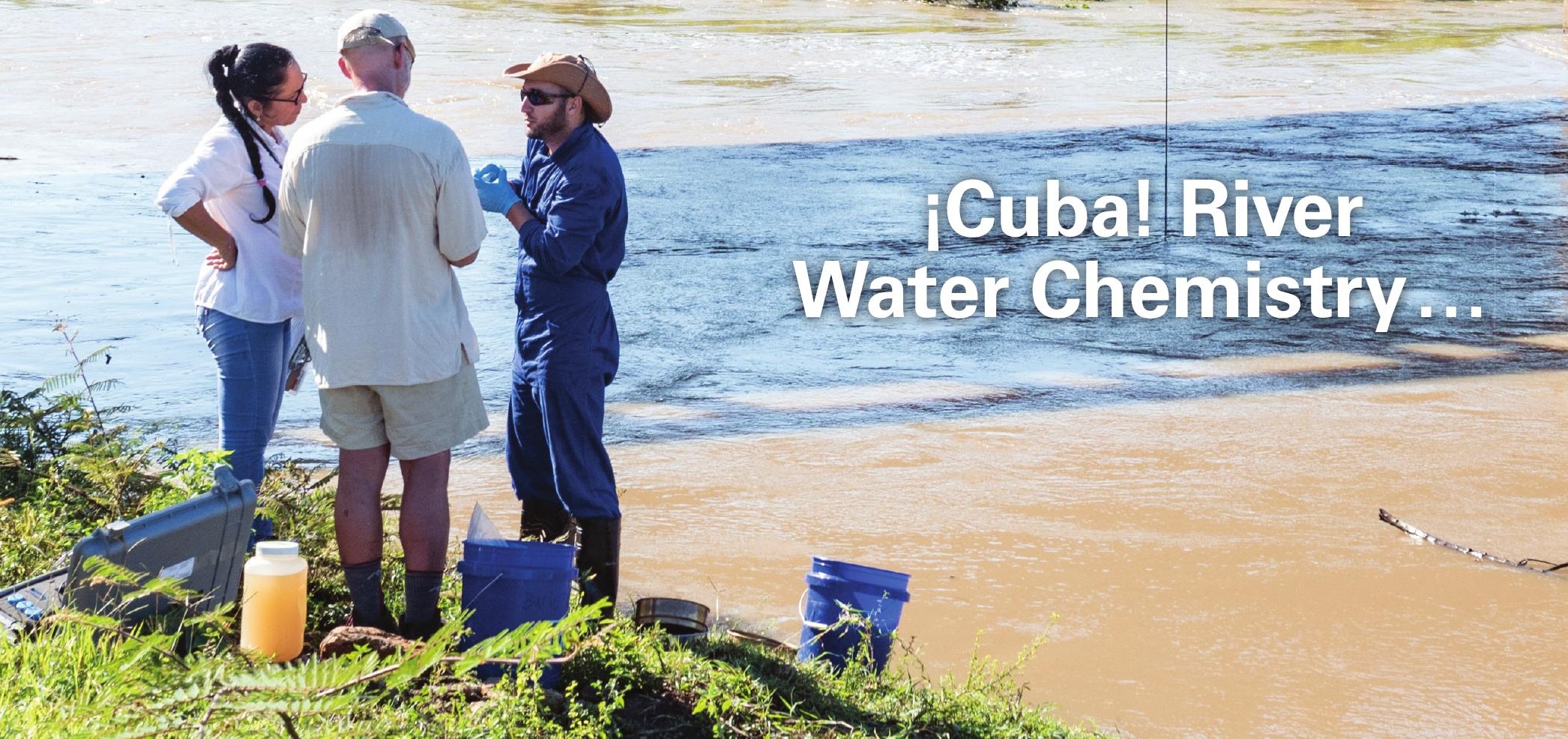




\section{¡Cuba! River Water Chemistry Reveals Rapid Chemical Weathering, the Echo of Uplift, and the Promise of More Sustainable Agriculture}

Paul Bierman, Dept. of Geology and Gund Institute for Environment, University of Vermont, Burlington, Vermont 05405, USA; Rita Yvelice Sibello Hernández, Centro de Estudios Ambientales de Cienfuegos, Cienfuegos, Cuba; Amanda H. Schmidt, Geology Dept., Oberlin College, Oberlin, Ohio 44074, USA; Héctor Alejandro Cartas Aguila, Yoelvis Bolaños Alvarez, Aniel Guillén Arruebarrena, Centro de Estudios Ambientales de Cienfuegos, Cienfuegos, Cuba; Mae Kate Campbell, Dept. of Geology and Gund Institute for Environment, University of Vermont, Burlington, Vermont 05405, USA; David Dethier, Geosciences Dept., Williams College, Williamstown, Massachusetts 01267, USA; Monica Dix, Geology Dept., Oberlin College, Oberlin, Ohio 44074, USA; Marika Massey-Bierman, Geosciences Dept., Williams College, Williamstown, Massachusetts 01267, USA; Alejandro García Moya, Centro de Estudios Ambientales de Cienfuegos, Cienfuegos, Cuba; Julia Perdrial, Dept. of Geology and Gund Institute for Environment, University of Vermont, Burlington, Vermont 05405, USA; Jason Racela, Geosciences Dept., Williams College, Williamstown, Massachusetts 01267, USA; Carlos Alonso-Hernández, Centro de Estudios Ambientales de Cienfuegos, Cienfuegos, Cuba

\section{ABSTRACT}

For the first time in more than half a century, a joint Cuban/American science team has worked together to quantify the impacts of chemical weathering and sustainable agriculture on river water quality in Cuba- the largest and most populous Caribbean island. Such data are critical as the world strives to meet sustainable development goals and for understanding rates of landscape change in the tropics, an understudied region. To characterize the landscape, we collected and analyzed water samples from 25 rivers in central Cuba where upstream land use varies from forested to agricultural.

Cuban river waters bear the fingerprint of the diverse rock types underlying the island, and many carry exceptionally high dissolved loads. Chemical denudation rates are mostly among the top $25 \%$ globally and are similar to those measured in other Caribbean islands. High rates of solute export and the distinct composition of the waters in specific basins suggest flow paths that bring river source waters into contact with fresh, weatherable rock-unusual in a warm, wet, tropical climate where weathering should extend deep below the surface. Tectonically driven uplift likely maintains the supply of weatherable material, leading to channel incision and, thus, to the exposure of bedrock in many river channels.

Despite centuries of agriculture, the impact on these rivers' biogeochemistry is limited. Although river water in many central Cuban rivers has high levels of $E$. coli bacteria, likely sourced from livestock, concentrations of dissolved nitrogen are far lower than other areas where intensive agriculture is practiced, such as the Mississippi River Basin. This suggests the benefits of Cuba's shift to conservation agriculture after 1990 and provides a model for more sustainable agriculture worldwide.

\section{INTRODUCTION}

The Republic of Cuba (Fig. 1) has more than 11 million inhabitants, but there has been little collaboration between U.S. and Cuban scientists for more than half a century although only $160 \mathrm{~km}$ separates the two countries (Feder, 2018). River biogeochemistry data, which are sparse in tropical regions, are needed to guide sustainable development in Cuba and, by example, in other tropical and island nations.

Here, we present and interpret extensive new data characterizing river waters in central Cuba, the result of a bi-national, collaborative field campaign. Biogeochemical analyses allow us to address fundamental geologic questions, such as the pace of chemical weathering in the tropics, as well as applied environmental questions related to the quality of river water and human impacts on a landscape where small-scale, sustainable farming has replaced substantial swaths of industrial agriculture (The Guardian, 2017).

\section{BACKGROUND AND METHODS}

Cuba's wet, warm tropical landscape is dominated by mountains (up to $1917 \mathrm{~m}$ above sea level [asl] in the east, 500-700 m asl elsewhere) running parallel to the north and south coasts (Fig. 1). Mainly forested uplands descend into farmed rolling plains and mangrove-lined, low-lying coastal estuaries. The climate is summer-wet and

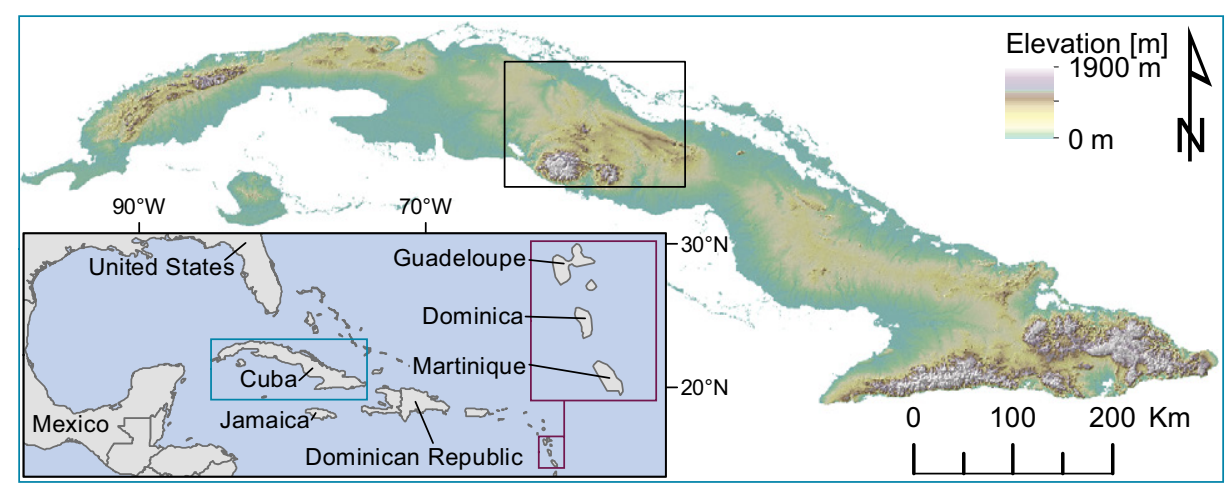

Figure 1. Cuba with elevation as color ramp. Black outline is area mapped in Figure 3. Inset shows location of Cuba in relation to North America. 
winter-dry with precipitation delivered both by trade-wind showers and by larger tropical storms.

The diverse geology of Cuba reflects its tectonic setting at the boundary of the North America and Caribbean plates. Central Cuban basement lithologies include accreted igneous rocks, sediments (clastic, carbonate, and evaporite) formed along passive margins, obducted ophiolite, and island arc rocks (Iturralde-Vinent et al., 2016). This basement is unconformably overlain by slightly deformed, younger marine and terrestrial sedimentary rocks (IturraldeVinent, 1994). Where river water has interacted with these diverse rocks, surface water chemistries should reflect the composition of underlying rock units.

Agriculture has been practiced in Cuba for centuries. Indigenous people cultivated cassava, yucca, and maize (Cosculluela, 1946). Spanish colonization from 1492 brought slaves, large-scale sugar agriculture, and cattle farming (Zepeda, 2003). Following Cuba's independence from Spain in 1898, sugar production in Cuba quadrupled under U.S. influence (Whitbeck, 1922). When Cuba allied with the Soviet Union in 1959, industrialization of the sugar industry to increase yields and exports became a central goal (Pérez-López, 1989). By the 1980s, Cuba boasted the most mechanized agricultural sector in Latin America (FeblesGonzález et al., 2011); however, the collapse of the Soviet Union in 1991 catalyzed Cuban adoption of reduced tillage, organic soil amendments, the use of cover crops, and the replacement of fuel-hungry tractors with domesticated draft animals, including horses and oxen (Gersper et al., 1993).

Surface water biogeochemical monitoring in central Cuba has focused mainly on reservoirs. In central Cuba, water chemistry data (1986-2005) from four reservoirs, representing two river systems and four basins with varied geology (Betancourt et al., 2012) showed that the primary control on major ion concentration is rock weathering upstream; there was no statistically significant difference in water chemistry between dry and rainy seasons in three of the four basins.

In August 2018 (the wet season), we collected water samples from 25 river basins in central Cuba. We selected these sites to encompass a range of land uses, underlying upstream rock types, discharges, and basin sizes, while avoiding rivers that had major dams (Figs. 2 and 3N). See the GSA Data Repository ${ }^{1}$ for detailed methods. Our analysis assumes that the concentration of cations and anions we measured are representative of annual average values (Godsey et al., 2009).

\section{RESULTS}

River water samples from central Cuba contain high concentrations of dissolved material (Figs. 3 and 4). Conductivity and total dissolved load were high (130-1380 $\mu \mathrm{S} / \mathrm{cm}$ and 117 to over $780 \mathrm{mg} / \mathrm{L}$, respectively, Tables S1 and S2 [see footnote 1]); stream water, except that sampled from forested catchments, was turbid. Sample $\mathrm{pH}$ was near neutral to slightly alkaline with high values of bicarbonate alkalinity (65$400 \mathrm{mg} / \mathrm{L}$ ). As, Ba, Cr, Mn, Ni, Sr, and U were present in some or all of the Cuban river waters we analyzed, in all cases at levels below drinking water standards (Table S3 [see footnote 1]). Dissolved oxygen measured in the field ranged from $59 \%$ to $145 \%$ (average 97\%). Using basin-specific precipitation (Fig. 3), along with run-off estimates (Beck et al., 2015, 2017) and total dissolved solids (TDS) from each Cuban water sample, we estimate chemical weathering rates between 42 and $302 \mathrm{t} \mathrm{km}^{-2} \mathrm{y}^{-1}$ with a mean of $161 \pm 66 \mathrm{t} \mathrm{km}^{-2} \mathrm{y}^{-1}$.

Dissolved organic carbon (DOC) was highly variable, ranging from $<1 \mathrm{mg} / \mathrm{L}$ to $9 \mathrm{mg} / \mathrm{L}$ (Table S4 [see footnote 1]). Total dissolved nitrogen (TDN) ranged from $<0.1-1.5 \mathrm{mg} / \mathrm{L}($ mean $=0.76 \mathrm{mg} / \mathrm{L})$; on average $60 \%$ was present as nitrate (range $24 \%-$ $93 \%$ ). Nitrate values measured in the field and then in the lab several weeks later are well correlated. Nitrite was present in all samples, averaging $1.2 \mathrm{mg} / \mathrm{L}(0.37 \mathrm{mg} / \mathrm{L}$ of $\mathrm{N})$. DOC/TDN ratios also vary widely, from 1.3 to 14.8 . Anion concentrations decreased in the order $\mathrm{HCO}_{3}>\mathrm{Cl}>\mathrm{SO}_{4}>\mathrm{NO}_{3}>\mathrm{HPO}_{4}$ $>\mathrm{NO}_{2}>\mathrm{Br}>\mathrm{F}$.

The anion orthophosphate (as P) was measured both in the field $(0.1-0.8 \mathrm{mg} / \mathrm{L})$ and lab $(0.4-0.5 \mathrm{mg} / \mathrm{L})$; field and lab analyses were positively correlated. Cations decreased on average in the order $\mathrm{Ca}>\mathrm{Na}>\mathrm{Mg}>\mathrm{Si}>\mathrm{K}$.

$E$. coli bacteria were found in all samples, and most samples (20/24) contained enough bacteria to be deemed unsafe for recreational use according to World Health Organization criteria (Most Probable Number (MPN) > $127 / 100 \mathrm{ml}$ ). Genetic microbial source trac- ing in two samples with MPN/100ml $>1000$ (CU-107 and 110) did not identify any humansourced bacteria; rather, the bacteria in sample CU-110 were identified as being of ungulate origin, and no specific source could be determined for bacteria in CU-107.

There are numerous correlations between anions and cations in our river water samples (Table S5 [see footnote 1]). $\mathrm{Na}$ and $\mathrm{Cl}$ are positively correlated $(\mathrm{p}<0.01)$ as well as $\mathrm{Na}$ and $\mathrm{HCO}_{3}, \mathrm{~F}, \mathrm{SO}_{4}, \mathrm{NO}_{2}, \mathrm{~K}, \mathrm{Ca}, \mathrm{Br}, \mathrm{Ti}$, $\mathrm{As}, \mathrm{Rb}, \mathrm{Sr}, \mathrm{Ba}$, and $\mathrm{U}(\mathrm{p}<0.05$, all positive, Fig. 4). These elements are also correlated to one another positively and significantly. In addition, $\mathrm{Mg}$ is positively correlated to $\mathrm{SiO}_{2}, \mathrm{~V}, \mathrm{Cr}$, and $\mathrm{Ni}(\mathrm{p}<0.05)$. $\mathrm{NO}_{2}$ is positively correlated with conductivity.

Four of the 25 samples (CU-120, -121, -122 , and -132), all collected in the northwestern part of the field area, are geochemically distinct (Figs. 3, 4, and 5). These samples have the highest or nearly highest $\mathrm{Cl}$, $\mathrm{SO}_{4}, \mathrm{Br}, \mathrm{NO}_{2}$, and $\mathrm{Na}$ concentrations, field conductivity, and TDS (Fig. 4, red symbols) in the sample set. These are four of only five samples to contain low but measurable As (1.0-1.4 ppb). They plot in a distinct zone of the Piper diagram (Fig. 5) and also have higher $\mathrm{Rb}, \mathrm{Sr}, \mathrm{Ba}$, and $\mathrm{U}$ concentrations (1.8-4.3 ppb) than other Cuban river water samples. Three of the four samples contain $>115 \mathrm{mg} / \mathrm{L} \mathrm{Ca}$ and high concentrations of $\mathrm{Na}, \mathrm{Cl}$, and $\mathrm{SO}_{4}$. These four samples were collected near one another and drain the same bedrock map unit (postEocene marine sediment). One (CU-122) drains mostly wetland while the others drain dominantly agricultural catchments.

\section{DISCUSSION/INTERPRETATION}

\section{Bedrock Controls Central Cuban River Water Chemistry}

In central Cuba, river water composition and TDS covary with rock types (Figs. 3 and 4D) suggesting a close connection between river water chemistry and underlying rock units. For example, high concentrations of $\mathrm{Ca}, \mathrm{Mg}$, and alkalinity in most samples are consistent with the mapped presence of carbonate rocks in most sampled drainage basins (Fig. 3). Distinct anion, cation, and trace metal compositions of rivers draining four (CU-120, -121, -122, -132) watersheds in the NW quadrant of our field area and underlain by marine sediments (French and Schenk, 2004) suggest dissolution of evap- 

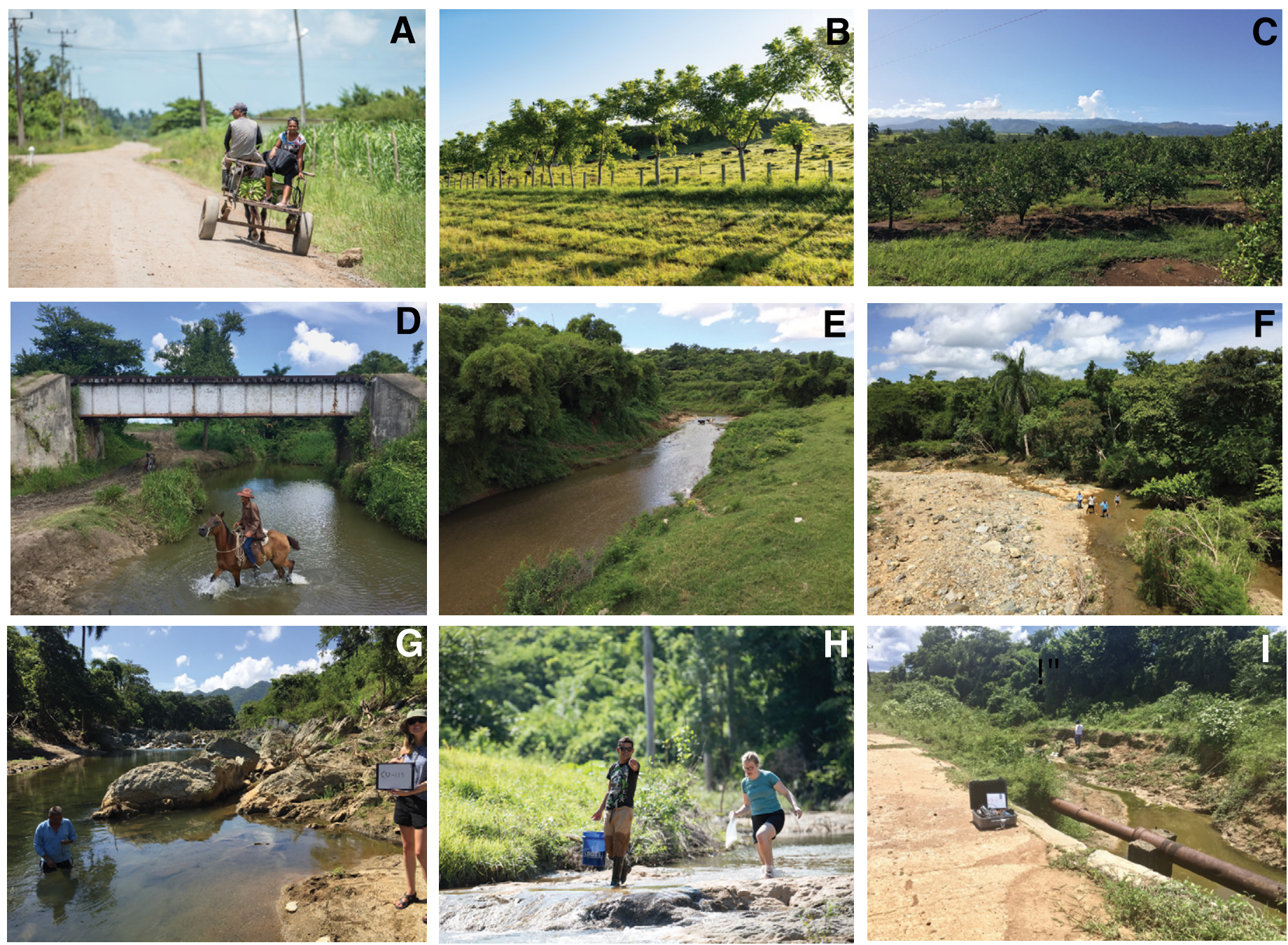

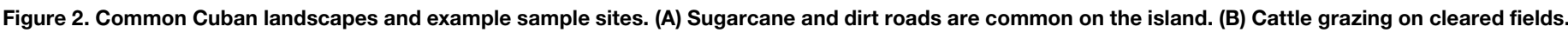

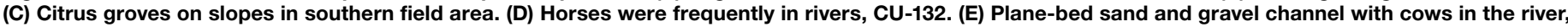

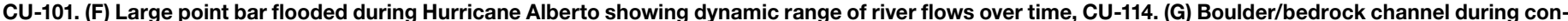

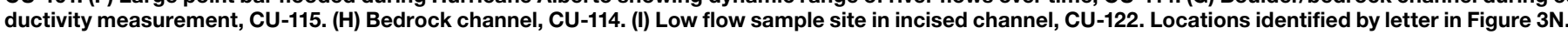

orite deposits including those that contain nitrite (Figs. 3, 4, and 5).

The relationship between water chemistry and bedrock type in central Cuba suggests the presence of fresh, weatherable mineral surfaces along flow paths carrying subsurface flow to Cuban rivers. This inference is supported by comparison of Cuban river water chemistry with that from Martinique, Guadeloupe, and Dominica (Rad et al., 2013). The latter three islands are underlain primarily by andesite, and their surface water contains more $\mathrm{Si}$ and $\mathrm{K}$ and less $\mathrm{Ca}$ and $\mathrm{Mg}$ than Cuban rivers (Fig. $6 \mathrm{~A})$. The higher concentration of most other anions and cations in Cuban waters as compared to waters from volcanic Caribbean islands reflects the influence of readily soluble carbonate and evaporite rocks in Cuba. Although average TDS for waters from
Cuba exceeds that on other, e.g., volcanic, Caribbean islands (Fig. 6A), chemical denudation rates estimated from central Cuban river water samples are similar to other Caribbean islands (Fig. 6B) because mean annual precipitation and thus runoff in Cuba is lower. All Caribbean chemical denudation rates are high when compared to global data (Larsen et al., 2014).

Field observations of incised, bedrockfloored river channels and the chemical data that mandate extensive water/rock interaction similar to that on tectonically active, volcanic Caribbean islands suggest ongoing bedrock uplift in central Cuba rather than tectonic stability and the development of a deep tropical weathering mantle. Raised marine terraces along southern and eastern Cuba (Muhs et al., 2017) are consistent with such uplift, which, along with tectonically induced rock fracturing, is likely responsible for the continued supply of fresh, easily weatherable rock, and thus high chemical weathering rates.

\section{Human Activities and Water Quality}

High TDS in central Cuban river water as a result of bedrock chemical weathering is not hazardous but could limit some uses. About $20 \%$ of samples we collected have TDS and Na levels above the taste threshold. High TDS samples may cause $\mathrm{CaCO}_{3}$ scaling on pipes, household cooking implements, and industrial equipment; scaling could be a health benefit if lead remains in the water distribution system. High levels of DOC (up to $9 \mathrm{mg} / \mathrm{L}$ ) in central Cuban river water suggest a potential risk of trihalomethane formation during chlorination (Engelage et al., 2009), which is the most 


\section{Lithologic Fingerprints}
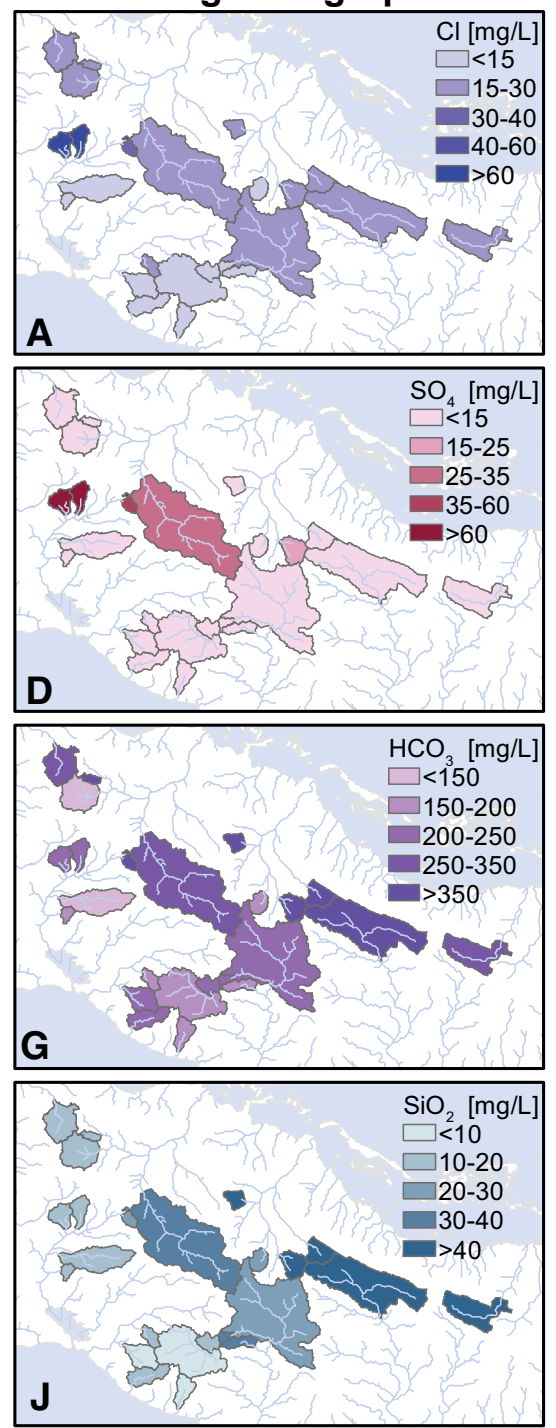

Dissolution Rates
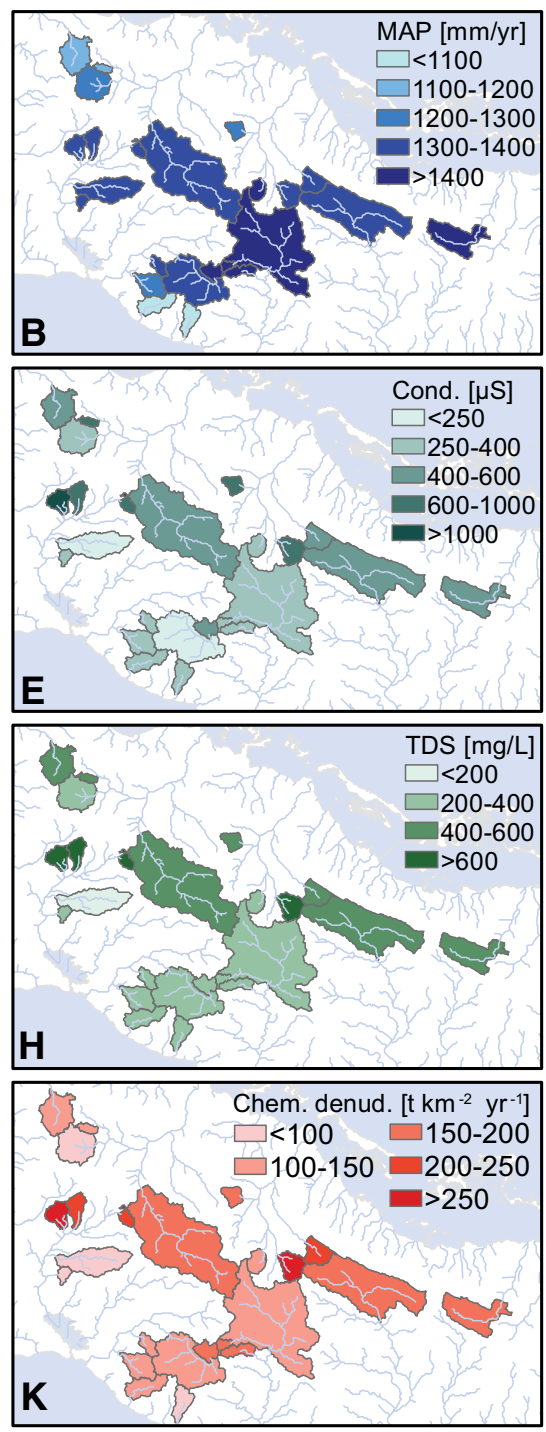

K

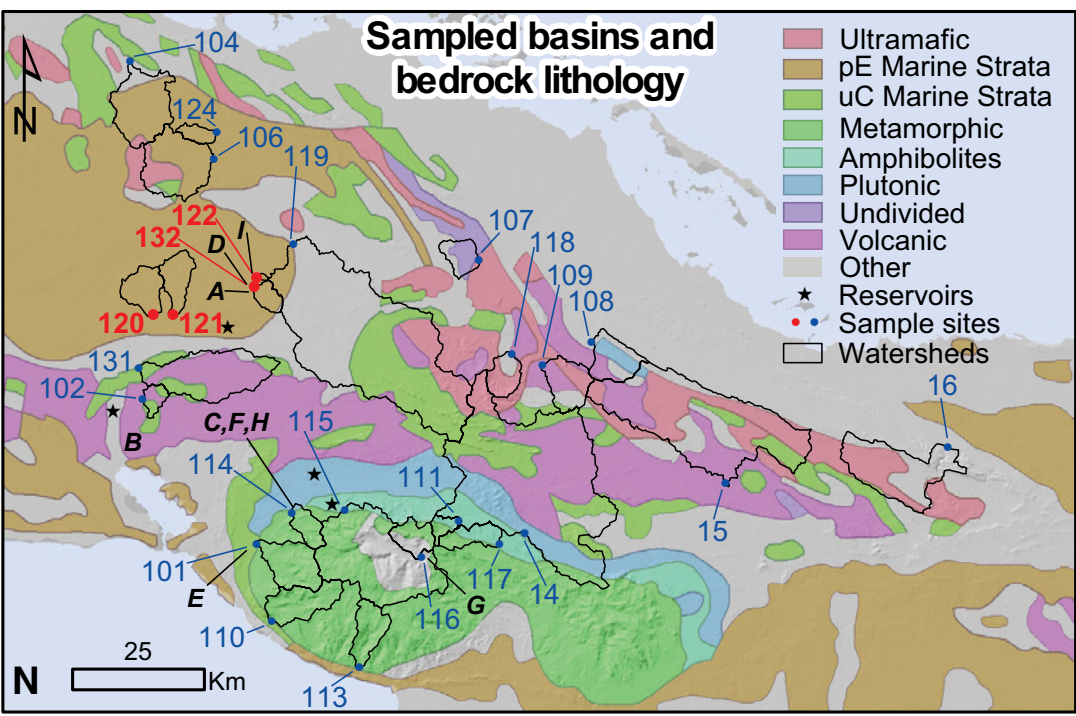

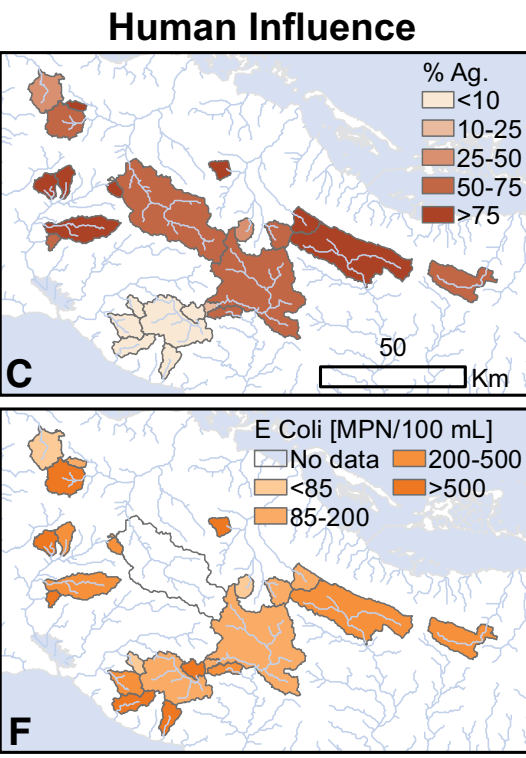
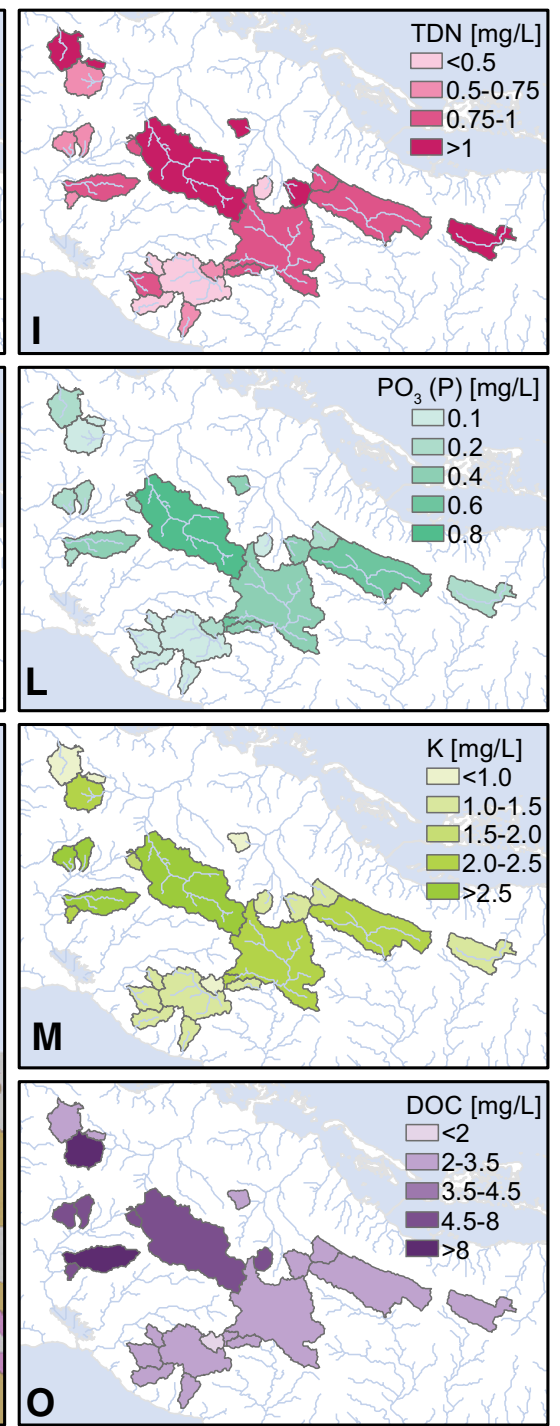

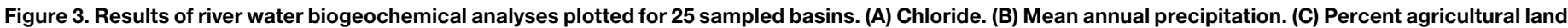

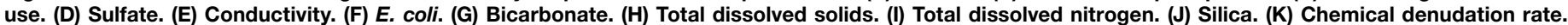

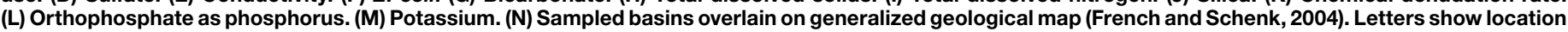

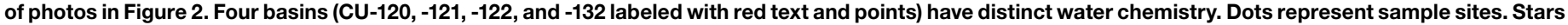
shows reservoir water samples (Betancourt et al., 2012). (O) Dissolved organic carbon. 


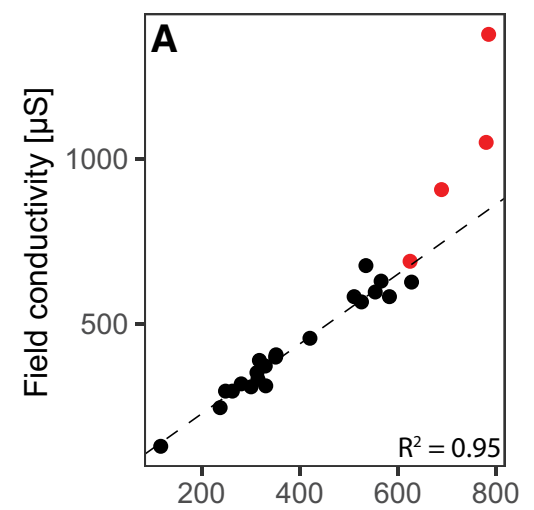

Total dissolved solids [mg/L]
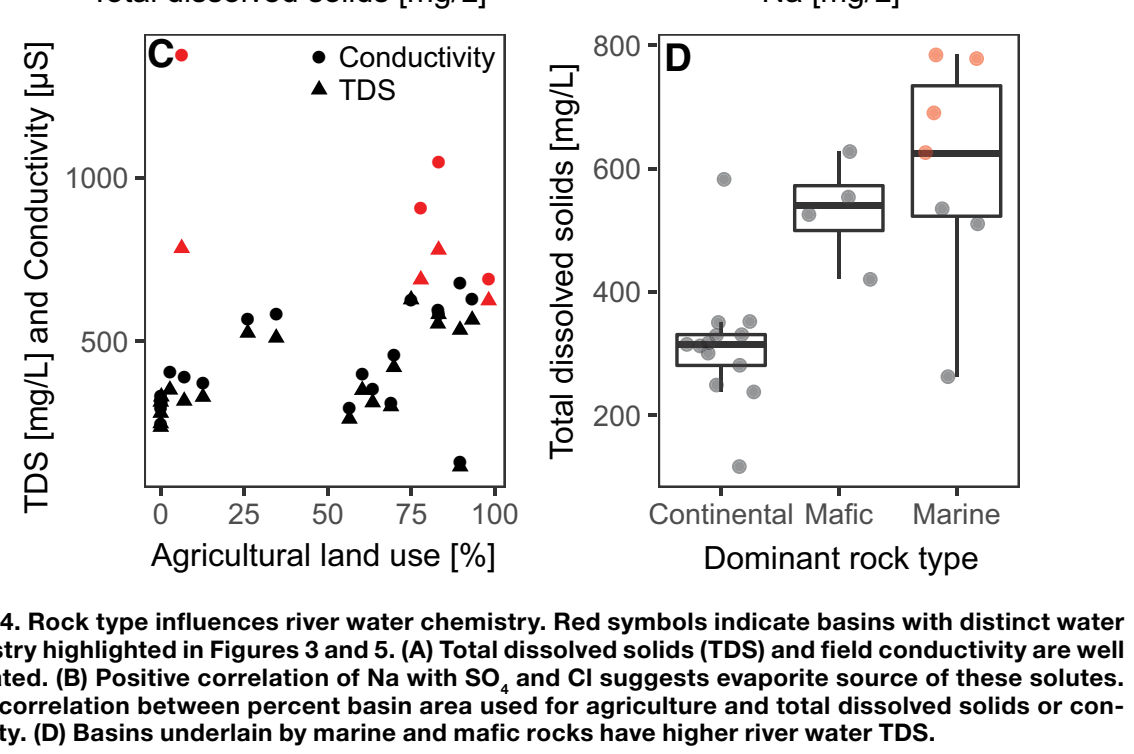

Figure 4. Rock type influences river water chemistry. Red symbols indicate basins with distinct water chemistry highlighted in Figures 3 and 5. (A) Total dissolved solids (TDS) and field conductivity are well correlated. (B) Positive correlation of $\mathrm{Na}$ with $\mathrm{SO}_{4}$ and $\mathrm{Cl}$ suggests evaporite source of these solutes. (C) No correlation between percent basin area used for agriculture and total dissolved solids or conductivity. (D) Basins underlain by marine and mafic rocks have higher river water TDS.
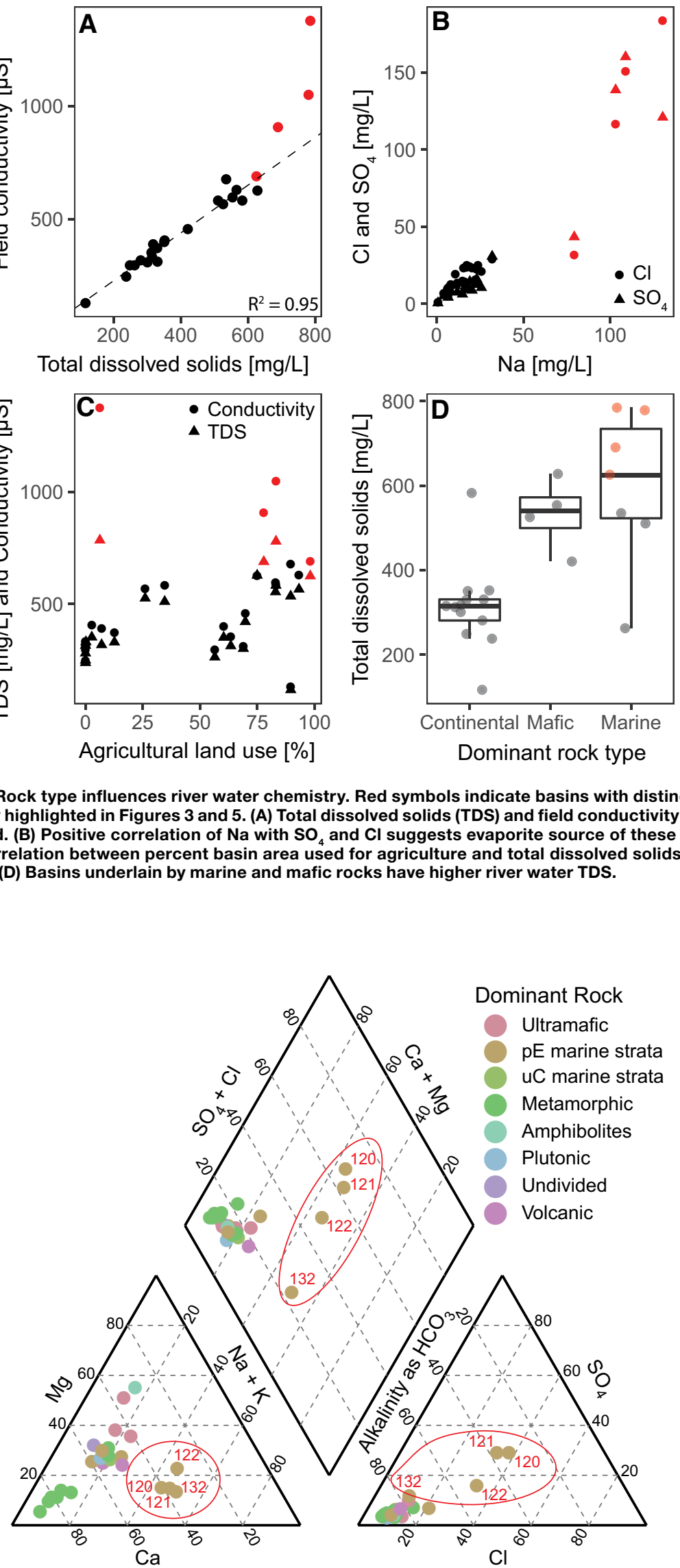

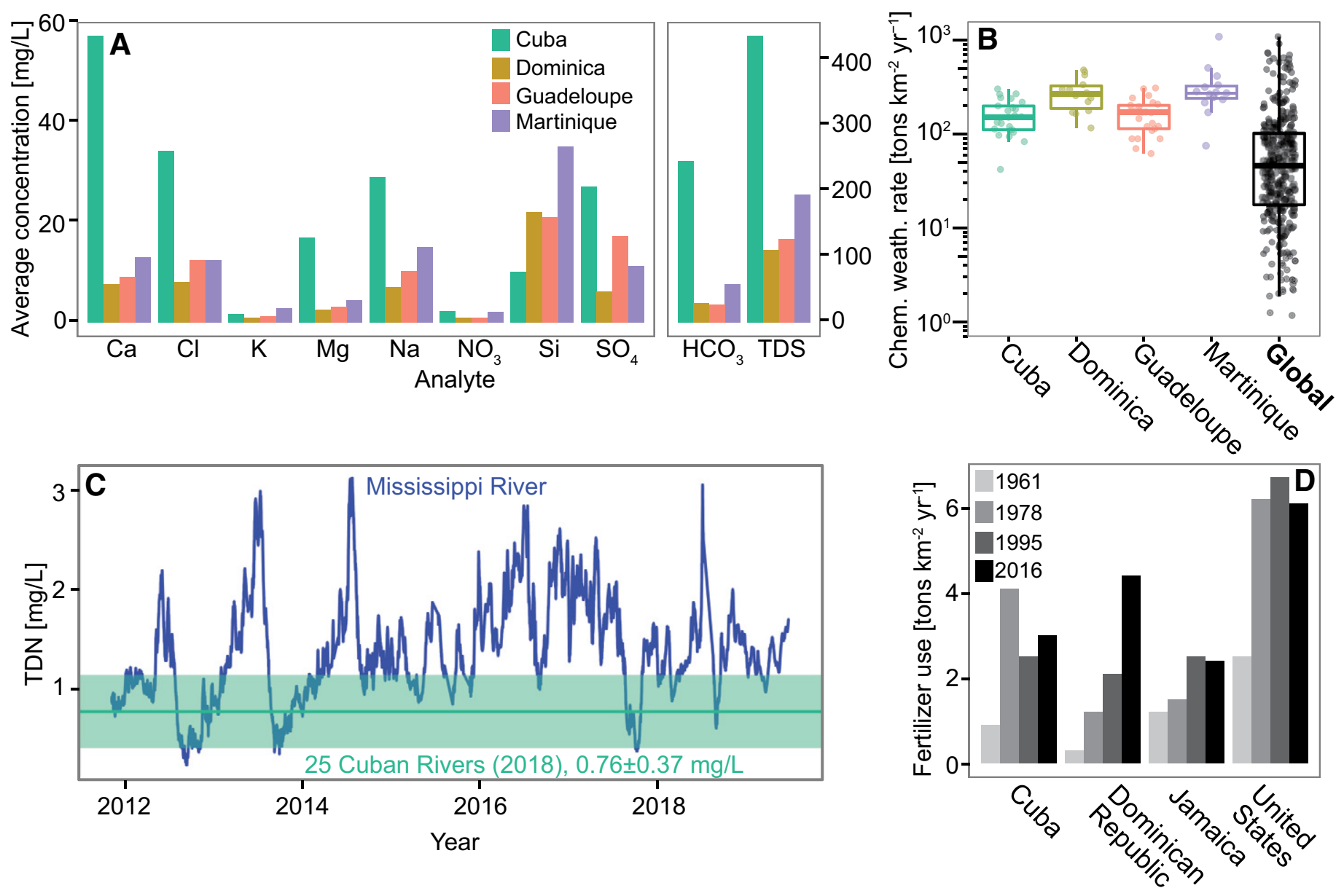

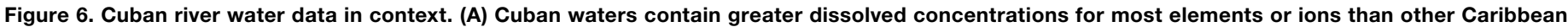

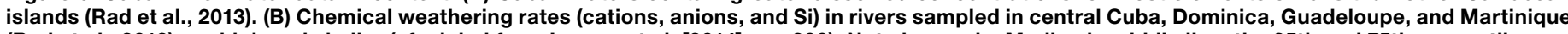

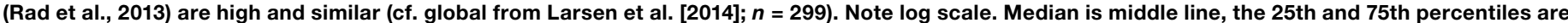

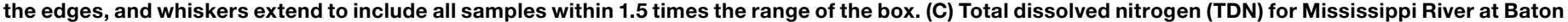

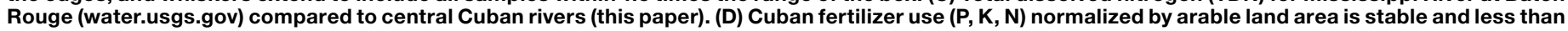
other nations. Data from https://data.worldbank.org/indicator/, Rawlins et al. (1998), and https://www.epa.gov/roe/.

\section{IMPLICATIONS}

Our data provide a comprehensive snapshot of the chemistry of water moving through rivers in central Cuba. From these data, we calculate high rates of rock weathering and landscape-scale denudation and thus infer the presence of flow paths through fresh rock or regolith supplying water to rivers we sampled-perhaps in response to tectonic uplift. Cuba's transition toward sustainable agriculture (and its reduced use of fertilizer per acre of crop land) results in much lower river-water nutrient concentrations in central Cuban rivers than in the Mississippi River - a model for other agricultural economies. Additional management strategies to reduce manure and sediment loads to rivers (such as fencing to keep cattle off river banks) could further and rapidly improve central Cuban river water quality. Reducing sediment and manure loads will have economic benefits, because rivers eventually discharge into the coastal zone where suspended sediment, and bacteria from agricultural activity, impact water quality and clarity on coral reefs and beaches frequented by tourists (Rawlins et al., 1998), a source of income to Cuba (Duffy and Kline, 2018).

\section{ACKNOWLEDGMENTS}

Support for field and analytic work provided by NSF EAR-1719249 and NSF EAR-1719240 to Bierman and Schmidt. Cuban researchers supported by the MICATIN and ISOAGRI projects. We thank W. Amidon, P. Ryan, and J. Smith (Middlebury College) for ICP-MS data and J. Brown UVM for photography. Some field costs and DNA tests supported by Oberlin College. We thank T. Dunne, B. McDowell, and students in University of Vermont Geology 351 for feedback on earlier versions of the manuscript.

\section{REFERENCES CITED}

Bachoon, D.S., Markand, S., Otero, E., Perry, G., and Ramsubhag, A., 2010, Assessment of nonpoint sources of fecal pollution in coastal waters of Puerto Rico and Trinidad: Marine Pollution Bulletin, v. 60, no. 7, p. 1117-1121, https://doi.org/ 10.1016/j.marpolbul.2010.04.020.
Beck, H.E., de Roo, A.D., and van Dijk, A.I.J.M., 2015, Global maps of streamflow characteristics based on observations from several thousand catchments: Journal of Hydrometeorology, v. 16, no. 4, p. 1478 1501, https://doi.org/10.1175/JHM-D-14-0155.1.

Beck, H.E., Vergopolan, N., Pan, M., Levizzani, V., van Dijk, A.I.J.M., Weedon, G.P., Brocca, L., Pappenberger, F., Huffman, G.J., and Wood, E.F., 2017, Global-scale evaluation of 22 precipitation datasets using gauge observations and hydrological modeling: Hydrology and Earth System Sciences, v. 21, p. 6201-6217, https://doi.org/ 10.5194/hess-21-6201-2017.

Betancourt, C., Suarez, R., and Jorge, F., 2012, Influence of natural and antropic processes on the water quality in four Cuban reservoirs: Limnetica, v. 31, p. 193-204.

Cosculluela, J.A., 1946, Prehistoric Cultures of Cuba: American Antiquity, v. 12, no. 1, p. 10-18, https://doi.org/10.2307/275809.

Cueto, J., and De Leon, O., 2010, Evaluation of Cuba's water and watershed infrastructure: Annual Meetings of the Association for the Study of the Cuban Economy Miami, Florida, https://www.ascecuba .org/asce_proceedings/appendix-b-evaluation -cubas-water-watershed-infraestructure-student 
-paper-presented-annual-meeting-not-included -printed-version-proceedings/ (accessed 7 Jan. 2020).

Duffy, L., and Kline, C., 2018, Complexities of tourism planning and development in Cuba: Tourism Planning \& Development, v. 15, no. 3, p. 211-215, https://doi.org/10.1080/21568316.2018.1440830.

Engelage, S., Stringfellow, W., and Letain, T., 2009, Disinfection byproduct formation potentials of wetlands, agricultural drains, and rivers and the effect of biodegradation on trihalomethane precursors: Journal of Environmental Quality, v. 38, p. 1901-1908, https://doi.org/10.2134/jeq2009.0015.

Febles-González, J.M., Tolón-Becerra, A., LastraBravo, X., and Acosta-Valdés, X., 2011, Cuban agricultural policy in the last 25 years: From conventional to organic agriculture: Land Use Policy, v. 28, p. 723-735, https://doi.org/10.1016/ j.landusepol.2010.12.008.

Feder, T., 2018, Physics in Cuba: Physics Today, v. 71, no. 3, p. 48-54, https://doi.org/10.1063/PT.3.3871.

French, C.D., and Schenk, C.J., 2004, Map showing geology, oil, and gas fields, and geologic provinces of the Caribbean Region: U.S. Geological Survey Open-File Report 97-470-K, https://pubs.usgs .gov/of/1997/ofr-97-470/OF97-470K/ (accessed 7 Jan. 2020).

Gersper, P.L., Rodríguez-Barbosa, C.S., and Orlando, L.F., 1993, Soil conservation in Cuba: A key to the new model for agriculture: Agriculture and Human Values, v. 10, no. 3, p. 16-23, https://doi.org/10.1007/BF02217835.

Godsey, S.E., Kirchner, J.W., and Clow, D.W., 2009, Concentration-discharge relationships reflect chemostatic characteristics of US catchments: Hydrological Processes, v. 23, no. 13, p. 18441864, https://doi.org/10.1002/hyp.7315.
Guardian, The, 2017, Organic or starve: Can Cuba's new farming model provide food security?: The Guardian, 28 Oct. 2017, https:/www.theguardian .com/environment/2017/oct/28/organic-or-starve -can-cubas-new-farming-model-provide-food -security (accessed 16 Dec. 2019).

Iturralde-Vinent, M., 1994, Cuban geology: A new plate-tectonic synthesis: Journal of Petroleum Geology, v. 17, no. 1, p. 39-69, https://doi.org/ 10.1111/j.1747-5457.1994.tb00113.x.

Iturralde-Vinent, M., Garcia-Casco, A., Rojas-Agramonte, Y., Proenza, J., Murphy, J.B., and Stern, B., 2016, The geology of Cuba: A brief overview and synthesis: GSA Today, v. 26, no. 10, p. 4-10, https://doi.org/10.1130/GSATG296A.1.

Larsen, I.J., Montgomery, D.R., and Greenberg, H.M., 2014, The contribution of mountains to global denudation: Geology, v. 42, no. 6, p. 527 530, https://doi.org/10.1130/G35136.1.

Muhs, D.R., Schweig, E.S., Simmons, K.R., and Halley, R.B., 2017, Late Quaternary uplift along the North America-Caribbean plate boundary: Evidence from the sea level record of Guantanamo Bay, Cuba: Quaternary Science Reviews, v. 178, p. 54-76, https://doi .org/10.1016/j.quascirev.2017.10.024.

Obenour, D.R., Scavia, D., Rabalais, N.N., Turner, R.E., and Michalak, A.M., 2013, Retrospective analysis of midsummer hypoxic area and volume in the northern Gulf of Mexico, 1985-2011: Environmental Science \& Technology, v. 47, no. 17, p. 9808-9815, https://doi.org/10.1021/es400983g.

Pérez-López, J.F., 1989, Sugar and structural change in the Cuban economy: World Development, v. 17, no. 10 , p. 1627-1646, https://doi.org/ 10.1016/0305-750X(89)90033-8.

Pommepuy, M., Derrien, A., Le Guyader, F., Menard, D., Caprais, M.P., Dubois, E., and Gourmel- on, M., 2000, Microbial water quality on a Caribbean Island (Martinique): Small Islands, Big Issues, v. 37, no. v, p. 284-297.

Rad, S., Rivé, K., Vittecoq, B., Cerdan, O., and Allègre, C.J., 2013, Chemical weathering and erosion rates in the Lesser Antilles: An overview in Guadeloupe, Martinique and Dominica: Journal of South American Earth Sciences, v. 45, p. 331344, https://doi.org/10.1016/j.jsames.2013.03.004.

Rawlins, B.G., Ferguson, A.J., Chilton, P.J., Arthurton, R.S., Rees, J.G., and Baldock, J.W., 1998, Review of agricultural pollution in the Caribbean with particular emphasis on small island developing states: Marine Pollution Bulletin, v. 36, no. 9, p. 658-668, https://doi.org/10.1016/ S0025-326X(98)00054-X

Riera, A.J., 1994, Cattle: The Forgotten Industry: Miami, Florida, Annual Proceedings of the Association for the Study of the Cuban Economy, v. 4, abstract \#63, http://www.ascecuba.org/publications/ annual-proceedings/cuba-in-transition-volume -04/ (accessed 7 Jan. 2020).

Wampler, P., and Sisson, A., 2011, Flow, bacterial contamination, and water resources in rural Haiti: Environmental Earth Sciences, v. 62, no. 8, p. 1619 1628, https://doi.org/10.1007/s12665-010-0645-9.

Whitbeck, R.H., 1922, Geographical relations in the development of Cuban agriculture: Geographical Review, v. 12, no. 2, p. 223-240, https://doi.org/ $10.2307 / 208738$.

Zepeda, L., 2003, Cuban agriculture: A green and red revolution: Choices: The Magazine of Food, Farm, and Resource Issues, v. 18, 4th quarter, 5 p.

MANuSCRIPT RECEIVED 17 July 2019

REVISED MANUSCRIPT RECEIVED 17 DEC. 2019

MANUSCRIPT ACCEPTED 20 DEC. 2019 